more than a small number of persons. On the other hand, shortage of protective food elements affects many millions, and the effective absorption as well as the actual consumption of essential food elements requires consideration. Since this is affected, for example, by exercise and fresh air, these may also be ancillary factors in nutrition. The most serious and widespread form of malnutrition at the present time in Great Britain is probably the deficiency of calcium among children and adolescents, but there is also insufficient consumption of fresh fruit, vegetables and fats, although in the present state of knowledge the deficiency cannot be measured. The most pressing nutritional needs are, however, clearly indicated, and Government and industry carry a heavy responsibility for taking the necessary steps to meet these needs. Not the least valuable feature of this admirable broadsheet is a list of reports and books on nutrition.

\section{Roman Leicester}

LEICESTER has saved her Roman remains. At a meeting of the City Council held on February 23, it was decided that the site of the Roman Forum, recently discovered in the course of the excavations carried out by Miss Kathleen Kenyon (see Nature, $138,356,432$ ) should be preserved as an open space for all time. As the site is centrally situated and had been chosen for the erection of municipal baths, it will be widely appreciated that the citizens of Leicester by this decision have shown a generous public spirit in their attitude towards the claims of the past and a consciousness of their obligation to the nation at large and to posterity, which is worthy of all praise. Of this monument, unique in Britain, the excavations have now proceeded to a point which reveals two sides of the Forum with one of the flanking streets; while it has been shown that the famous "Jewry Wall", one of the largest pieces of Roman work in England, was part of the west wall of the basilica. In later times this became a place of Christian worship, and in the early medieval period the Jewry Wall itself was utilized as the west end of a church. Tiles and bricks from the Forum were used in the construction of the adjacent late Saxon church of St. Nicholas, itself one of the notable monuments of Leicester. It has been pointed out that in declaring that this area shall remain in perpetuity an open space, the Council preserves in the heart of the city "the veritable birth-place of her commerce, her self-government, and her religion"; but in fact it does even more. For Miss Kenyon in the course of her excavations has discovered traces of pre-Roman settlement, which may well go back to the original British village founded on the banks of the Soar. The City of Leicester is to be congratulated on a decision which will earn the gratitude of all who are interested in the preservation of such relics of the past.

\section{An Experiment in Science Teaching}

IN discussing some time ago certain aspects of university science teaching (NATURE, 129, 773-5; 1932), doubts were expressed of the present-day necessity for, or desirability of, extensive spoonfeeding lecture and laboratory courses in universities. In proposing some changes, a plea was made for incorporating into science teaching some instruction in scientific method. An interesting development on these lines is being carried out by Prof. A. J. Riker in the University of Wisconsin in a laboratory class in plant pathology. Instead of using the same set of exercises repeated by each member of the class, the routine laboratory manipulations are acquired in carrying out simple investigations. Most members of the class work on different subjects, and compare the results freely. When a piece of work has been completed, a time is arranged and the student gives a short account and demonstration, after which the results are discussed by the other members of the class.

To facilitate the supervision, Prof. and Mrs. Riker have published in a limited edition "An Introduction to Research on Plant Diseases" (Madison, Wis.: Prof. A. J. Riker, College of Agriculture, University of Wisconsin, 1936. 2.65 dollars), giving a short account, with references to selected original papers, of the methods usually needed. Some of the chapters serve to guide the student in making his own systematic search of the literature before starting experimental work in the laboratory, in formulating his problem and his proposed plan of work clearly and in preparing an adequate report of the results. The more a method of teaching departs from a formalized routine, the more does its effect depend upon the actual supervisor, who must judge how much and how little help may be given to each individual. Much experience and analysis are then necessary before a supervisor may be able to help others to apply his new methods. Not infrequently in pioneer work the 'right' course of action may be adopted for what others may regard as a 'wrong' reason or rationalization. Since, however, there is little doubt that the methods of scientific workers could help in dealing with some of the major problems troubling present-day civilization, any attempts at developing educational methods so as to foster scien. tificaction deserve encouragement and close study.

\section{Institute of Chemistry}

AT the fifty-ninth annual general meeting of the Institute of Chemistry, held on March 1, the president, Dr. R. H. Pickard, stated that the membership now includes a roll of nearly 6,800 members and 800 registered students. This year, on October 2 , the Institute will attain the sixtieth anniversary of its original incorporation. The ideals of its founders have been steadily pursued. Chemistry, Dr. Pickard said, has established its place among the learned professions, and its practitioners are to be found in industry and commerce, in the Government and other public services. Chemists, by the very nature of their calling, have been for the most part of a retiring and modest disposition. Happily, there are also among them not a few who have developed a measure of business acumen. That is a matter of very great significance and importance. Everything 
possible should be done to encourage in the pro. fession a continuous supply of men of that type. There are, in the profession, young men, many as yet little known, who have courage and initiative to come forward with new work, to read papers, and to make useful and sensible contributions to discussions. To be able to express themselves clearly and with assurance on matters on which they can claim to know something is a valuable asset in itself. $\mathrm{He}$ would suggest to the younger members that much could be done to acquire this ability by good reading, by cultivating the habit of mixing with men of other professions, and by taking an active interest, not only in the proceedings of the societies devoted to their science, but also in the world of affairs generally. The supply of men and women for administrative posts is a difficult problem. There is another side of the question, however, namely, that in attaining an administrative post with the responsibility that it entails, there is a danger of the chemist losing touch with his science, so that it becomes more and more difficult for him to encourage the workers in the laboratories. Dr. Pickard was re-elected president of the Institute for the ensuing year.

\section{Smoke Reducing Grates for Domestic Use}

IN NATURE of January 23, an article on the prevention of smoke and dust emission referred to the difficulty experienced in burning raw coal smokelessly in the conventional open grate, and stated that investigations are now in progress having as their object the removal of this source of atmospheric pollution. The fundamental cause of smoke production from a domestic fire is the low temperature obtaining in the space above the fuel bed, combined with the cooling of the hot products of combustion by excess air entering the face of the grate. This normally gives rise to partial combustion of the hydrocarbon distillation products and the evolution of materials rich in carbon, but at certain periods, notably on kindling and on refuelling, the tarry matter may pass into the atmosphere unchanged.

To overcome these defects, a number of grate designs have been advanced, and the more important may be divided roughly into four classes. In the first, preheated air is supplied to the space above the fuel, increasing the temperature and promoting the early combustion of the volatile matter. This method can only be partially successful, as both the air supply and its temperature will be lowest just before adding a fresh charge. The second class, which is used in many multiple purpose grates, employs a draught which carries the distillates downwards through the hot fuel, giving conditions more suitable for their combustion. In these two, the smoke from the ignition charge is little altered. Gas is used in the third class as an auxiliary to burn the smoke. A novel example of this type was demonstrated recently by the Coal Utilisation Council, British Industries House, Marble Arch, London, W.1. The final class consists of more complicated devices in which the heat from the fire partially carbonizes raw coal contained in a suitable receptacle, the distillation products passing through the burning fuel where they are consumed. Dr. Arnot's smoke consuming grate (1855) was the forerunner of this type, but more recently a gravity feed from a hopper behind the fireback brings it more into line with modern ideas.

\section{Control of the Grid System in Great Britain}

IN a paper, read to the Institution of Electrical Engineers on February 10, Mr. J. D. Peattie describes the control rooms provided by the Central Electricity Board for controlling the generating stations supplying electricity to the grid and for supervising the operation of the transmission lines. The whole of Great Britain with the exception of northern Scotland is now divided into nine schemes. These are grouped into seven systems which are controlled from seven centres, at Glasgow, Newcastle, Leeds, Manchester, Birmingham, Bristol and London respectively. For short distances, continuous metallic circuits are provided, but for longer distances the Post Office channels pass through repeating stations and alternating current signals only are transmitted. The telephones and automatic indicating apparatus are always combined in one equipment suitable for use in conjunction with the channels hired from the Post Office. The vital line of communication is that connecting the control engineer on duty and the operator at the distant station.

IN general, the control engineer has access to, and a prior claim from his desk on, the outgoing channels. By means of automatic indicating apparatus he knows the position of the circuit breakers, the routine instruction signals and the readings of the load. In most cases the transmitting and receiving equipment for the signals are developments of apparatus used in automatic telephony. As a check on the frequency and time control carried out by the operators at the generating stations, meters connected to the local supply are installed in each control room. Differential dials are provided showing the difference between the time given by a high-grade standard clock and the system time given by the synchronous motor clocks. The standard clock is checked daily against the Greenwich radio time signal. Differential dials are also provided showing the difference between the time given by the standard clock and the system time given by a synchronous motor clock.

\section{Recent Acquisitions at the Natural History Museum}

AMONG recent acquisitions in the Department of Zoology are the mounted head of a Mexican bighorn sheep presented by Mr. John Lawson, the head of a Newfoundland caribou presented by Mr. W. Lawson, and the head of a woodland caribou presented by Captain D. A. Lawson. The study collection has been enriched by an Argali sheep skin from Samarkand, the gift of $\mathrm{Mr}$. Douglas Carruthers, and a tiger skin and skull from Perak presented by the Zoological Society. Miss Emma Hutchinson of Grantfield, Leominster, Herefordshire, has presented to the Museum the collection, contained in four cabinets, of British Lepidoptera made at Leominster by her 